\title{
TAKSU AND PANGUS AS AN AESTHETIC CONCEPT ENTITY OF BALI DANCE (A Case Study of Topeng Tua Dance)
}

\author{
I Nengah Mariasa \\ Department of Drama, Dance, and Music, State University of Surabaya \\ Lidah Wetan Surabaya, Surabaya 61177, Indonesia \\ E-mail: mariasainengah@gmail.com
}

Received: November 28, 2015. Revised: November 30, 2015. Accepted: December 4, 2015

\begin{abstract}
There are two types of topeng drama performance (topeng is Bahasa Indonesia for mask) in Bali, Topeng Pajegan and Topeng Panca. Topeng Pajegan is a masked drama performance that is danced by a dancer by playing various tapel, while Topeng Panca is danced by five dancers. Generally, there are three or four stages on topeng performance, i.e. panglembar, petangkilan, bebondresan, and/or pesiat. On panglembar stage, there is one dance represented the character of old people. The dance is then known as Topeng Tua (Old Mask). The costume, tapel, as well as hair worn by the dancer have been considered as one of the precious or noble artworks. The question comes up here, is the aesthetics of topeng only depended on its high aesthetic value costume and tapel? Topeng Tua performance technique is considerably not easy to be done by a beginner dancer. On the other words, it implicitly tells that the aesthetics of the dance depends closely to the dancers' techniques. A good Topeng Tua dancer will be able to dance by using the technique of ngigelang topeng. Furthermore, the beauty of Topeng Tua does not only lay on its splendor artworks on the costume, tapel, and hair colour, but more to the ability of the dancers' movement technique that successfully shows the beauty of taksu and pangus.
\end{abstract}

Keywords: taksu; pangus; ngigelang topeng; Topeng Tua

How to Cite: Mariasa, I. (2015). Taksu and Pangus As An Aesthetic Concept Entity of Bali Dance (A Case Study of Topeng Tua Dance). Harmonia: Journal of Arts Research and Education, 15(2), 107-112 doi:http://dx.doi.org/10.15294/ harmonia.v15i2.4557

\section{INTRODUCTION}

Topeng in Bali dance is a dance performance that tells about dialogues and songs. All dancers are required to wear a realist tapel with one special costume that can be used to dance various different roles. The word "tapel" has a similar meaning to "topeng" in Java and "mask" in English. It is a face cover used in several Yogyakarta and Surakarta dances. Here, if a topeng dancer plays four roles, he does not need to change his costume, but his mask and head costume equipment only.

Two types of topeng are normally used here, Topeng Pajegan and Topeng Panca (Bandem, 1983, p. 140). Topeng Pajegan is a dance performance that is done by a dancer by playing or moving various tapel based on the roles. Topeng Pajegan itself is also known as topeng wali because it is usually used in religious ceremony. The latter, that is topeng panca, is the developed version of Topeng Pajegan. It has more functions than the initial version. If the initial model is danced by one dancer, the latter is danced by five dancers, and so does with its other functions (Bandem and Rembang, 1976, pp. 11-13).

Topeng dance performance is gene- 
rally devided into three or four stages, i.e. panglembar, petangkilan,bebondresan, and/ or pesiat. Panglembar is the opening stage of topeng dance that is consisted of one to three dances. It is the stage where the meeting between the kingdom servants and their king is occurred, while, bebondresan is the performance of topeng roles that tend to be funny or comedy. The last stage is pesiat. It performes war. However, it is rarely performed now.

In the stage of panglembar, there is a dance that shows the character of an old man. The dance is known by Topeng Tua. Topeng Tua uses mask with a white-hairhead and an old face on the mask. The $t a-$ pel and costume of Topeng tua have been recognized as two noble artworks. Questions then can be derived from this phenomenon. Is the aesthetics of topeng dance only depended on the high valued costume and tapel? It is said that the magnetism of a dance depends closely to several aesthetic aspects. What are the aspects affected Topeng Tua dance that makes this dance is attracted for the audiences?

\section{METHOD}

The material object of this study is a Topeng Tua performance that is done by different dancers. The difference between dancers is shown in their level of ability in doing the dance technique up to the level of taksu. This is adjusted with the topic about aesthetics in Bali dance that becomes the formal objects of the research.

Data collected in this study is descriptive in a form of Topeng Tua performance recording and analyzed words using qualitative method. This study is employing two disciplinary approaches, ethnochoreology as well as aesthetics. As a paradigm, ethnochoreology employs basic assumptions, models, concepts, research methods, analytical methods, and analysis results (Ahimsa, 2007, p. 105). One if its assumption is that human wants to express themselves through dances that have certain functions and purposes.

The study is located not only in one particular area, but spread in several performance areas. Data are collected by using observation, interview, as well as documentation study techniques. The three observation techniques employed to complement each other. While observation and documentation study are emphasized to study the form and technique of the performance, interview is used here to understand the theories and its application in the performance.

Data and facts that have been collected are then analysed. The analysis is conducted under a particular process chain. Observation is initiated by an observation, continued by interviews and documentation study. Those there are done continuously started from the day when the data are collected. Further, from the data and empirical information, categorization is created based on the concepts and theories to see, classify, and relate one data into other data or facts.

\section{DISCUSSION}

The Topeng Tua dance performs movements of Bali dance 'putra manis', that is not belonged to Bali dance type bebancihan. The difference between 'putra manis' dance with bebancihan is on the movement in shoulder part. The shoulder gesture in 'putra manis' dance is the same as the basic movement in 'putra keras' dance, that is when the shoulder is lifted till the neck seems shorter. This kind of movement cannot be found in man dance bebancihan. In bebancihan, the neck is not lifted.

Topeng tua does not show dialogues and songs, but it shows only dance that employs the character of an old man. Even when this dance does not perform dialogues and songs, however, the level of diffulty of the dance is considerably high. A dancer is not only expected to master movements and to dance tapel, but also ngigelang topeng (dancing topeng or 'switching on' the tapel). Dancers are normally master this dance up to the level of ngigelang tapel, so that, it is less attractive ((Dibia, 2012, p. $68)$. For the clearer figure, please see figure 
1.

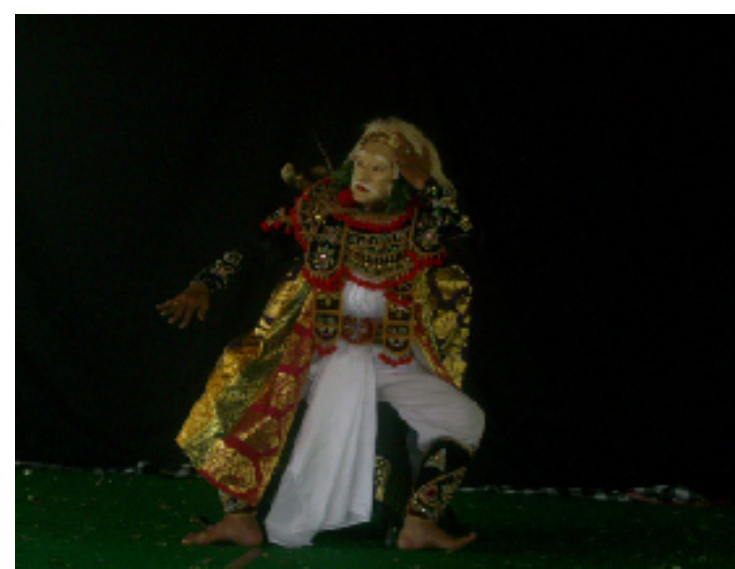

Figure 1. Visual Manifestation of Topeng Tua dance

The presentation (performance) technique of Topeng Tua dance is not easy to be done by a beginner dancer. One who has had an experience of performing tari putra or man dance, cannot be guaranteed to also will be mastering Topeng Tua well. They have to learn more on how to dig the dance technique of 'putra manis'. In nine stages of Bali dance learning, Topeng Tua dance belongs to the third or fourth stages. On the third stage, the dancers are expected to understand the techniques and its movements, whereas, on the fourth stage, they are expected to master tetuwek (soul) of the dance character (Bandem dan Dibia, 1982/1983, pp. 16-17). If the fourth stage can be mastered by a dancer, therefore, the dancer is considered to be able to dance by employing the concept of ngigelang topeng.

All the rules of movement techniques of Topeng Tua dance that may attract audiences are basically placed in two main aesthetic concepts, taksu and pangus. One of the tari topeng's maestro,

I Made Djimat, claimed that there is taksu besides pangus as the main aesthetic elements of Bali dance (Mariasa, 2000, pp. 166-171).

Taksu is believed as a magical strength from God that gives huge impact towards the beauty of Bali arts. Artworks or performance that have taksu in it is a kind of arts that has soul and live power
(Dibia, 2008, p. 30-31). Taksu is an inside power that contributes smartness, beauty, and miracle (Warna, et al., 1978, p.558). As a spiritual power, taksu penetrates inside a human soul, inside of the dancer especially, when they are dancing on stage. A dancer can be considered having taksu if he can transform himself as a whole perfectly based on his performed role. The condition on which the artist is gifted by such kind of gift, pushed the artists to perform magnificiently on the stage. In the other words, he is successfully control the movement technique that he performs (Bandem, 1996, p. 24).

Taksu can be also defined as a manifestation of pure culture creativity that delivers spiritual power towards an artist to reveal himself to be better than he is now. Taksu as a gift from God is a result of hard work, dedication, as well as surrender in pure state (Mantra, 1996, p. 26-27).

Taksu do not always come to the dancers right while they are performing on the stage (Interview: I Made Djimat, 24 December 1998). Sometimes, a dancer receives it hard, but sometimes it can be gotten easily and fast.

When the taksu covers a dancer, the dancer himself will perform with dazzling, immerse the feelings and thoughts of the audience into the performance. The beauty and aesthetics of the costume as well as the music accompaniment seem to be magnificient with the greatness of the dancers who dance it.

A complete preparation has to be had by a dancer if he wants taxes to be received faster by them. In its first preparation, a dancer has to master the movement technique ability. That is the most important requirement that has to be held by a dancer. The mastering movement technique cannot be done easily, a dancer has to spend his time, strength, as well as working hard while rehearsing the dance. If the ability of both movement and performing technique have been mastered by the dancer, the dancer needs to prepare and cultivate his confidence towards the miracle of taksu. Building belief inside the soul of a dancer 
is not an easy job to do. It needs an attempt to lay the dancer's soul to the God or to his profession. Further, it needs the dancer to hold the belief tightly based on the purpose that he wants to achieve.

How the taksu comes and goes is hard, but, it is surely can be felt. Made Djimat has ever delivered the term jeg (all ofa sudden) to refer to an aesthetic event that enters to the inside of the dancers' soul all of a sudden. When performing, in the very ready state, a dancer can suddenly control and dominate the audience's attention. The joy of dancing in that moment is immeasurable. With double strength, all movement techniques can be done easily. The dancer never suffers and feels burdened. On the other hand, he has maximum spirit to dance and his willingness to dance is bigger. As a result, the audience will be surprised and satisfied with the performance. However, in a reality, the kind of condition described above is considerably hard to be achieved.

In the reality, there is one thing that needs to be added here. Besides the readiness of the dancer, the place used to perform (kalangan) also become one distinguished factor here. Literally, kalangan is the place where the performance takes place. In fact, kalangan has double functions. Besides becoming the performance stage, it also has a special power to be given to the dancer. There is belief had by dancers that every kalangan has its own taksu. There is a kind of 'non- stingy' kalangan, and there is also the 'stingy' kalangan called demit (Catra, 1997, p. 108). In kalangan bares, a dancer can receive his taksu easier and faster. The contra action happened in $\mathrm{ka}$ langan demit. Further, Made Djimat argues that there is a contented kalangan and also an empty kalangan. Every movement that is danced can bhave more quality when the dancers dance in the contented kalangan. Conversely, the feeling of emptiness will be occurred when the dancers step their feet on the empty kalangan. A contented kalangan is considerably hard to be felt by audiences in general. However, an "experienced" dancer can feel whether the kalangan or the stage is contented or not. Made Djimat himself claims that he is able to feel the differences between those two kalangan. It is said that, the contented $k a-$ langan does not only exist in Bali but also in kalangan located in overseas. Contented or not a kalangan, however, has a high possibility to be affected by its initial construction process.

In Bali dance, the term 'pangus' is used as a term to refer to harmonization that supports an entity of the dance's role or characterization. Generally, in Balinese, the word 'pangus' means appropriate or harmonious (Warna, 1978, p. 414). Specifically, pangus is used to label to the suitability of someone's wearing and/ or doing something. In Bali dance, the word 'pangus' is used to refer to the conformity between themes and performance in a dance's role or characterization.

A role/ characterization in Bali dance is supported by several aspects, such as: movement, vocal, costume, as well as the music accompaniment. The movement supports the costume aspect and vice versa. All the aspects, together, will support shape the dance's characterization. As a result, a harmonious entity of dance will be formed. A beauty that arises from the unity is then known by pangus.

Each of the aspect has been organized neatly in Bali dance and has made the dance into an artistic dance. Nevertheless, the dance also needs to be performed by a skillful dancer. In this part, it can be said that the establishment of pangus is related closely to the ability of a dancer to perform it.

A dancer who has mastered the concept of pangus will always attempt to fuse his own personal character into his stage's role. He will hide the character that is not suitable with his on stage character. A dancer is allowed to develop an attitude that suits his on stage character when it is suitable to his personal life's character. A dancer who successfully performs a concept of pangus is believed to be able to perform well on stage.

According to this, it is believed that 
a caland prestigious role of dancer will be hard to be performed by a humorous and cheerful dancer. On the other hand, a cheerful or funny character will be easily performed by him. In this case, Topeng Tua dance is supposed to be perfomed with a movement and character that reflects an old man character that is far from funny, active, and strong characterization but more of a passionate, old and slow. All the spiritual movement is wrapped in a slow but passionate character that represents a character of an old man. An 'active' teenager dancer will be considered hard to dance or perform this type of role if he does not master the concept of pangus.

A dancer who goes deep into the concept of pangus is supposed to have mastered the initial or basic concept of dancing. While dancing on stage, a dancer will need to be fully concentrated. An attempt to fuse the dancer's personal character into the stage character is not easy to be done. A dancer has to realy concentrate to the dance he performs. Even a young dancer needs to bring the character of the old man onto the stage.

As one of the dominant aesthetic element, pangus is always seeked by almost every Bali dancer since they believe in the magnificience of pangus that may attract audiences. If a dancer has implemented pangus on stage, even the simplest movement on dance will be looked majestic. Madej Djimat sais that, "...cara ngigel babondresane, polos-polos igelane, awag-awagan ngigel, demen nak ningalin sawireh pangus" which means "as in babondresan, even if the movement is simple, the audiences may enjoy it to the fullest because of the pangus existence".

Taksu (bhawa) and pangus (anubhawa) are two important aspects in the aesthetic of Bali dance. The encounter between bhawa and anubhawa is cultivated by the dancers to establish a beauty or the aesthetic aspect of a dance (Ayasa, 1993, p. 46-47). Further, taksu tends to be inner (or the psychology of the dancer), while pangus is more physical. Taksu is an inside power, it refers to the dance intensity that is for- med as the combination between tension, tenderness, majesty, dignity, comedy, etc. It is supported by harmonious element of choreography that suits the theme of the dance. Intensity is a power. Pangus is a set of harmony that directs to a unity. The combination of taksu and pangus is a form of integrity concept that can be used to measure the aesthetic element of Topeng Tua. Special characteristics seen from the combination between these concepts are intensity (taksu) and harmony (pangus).

\section{CONCLUSION}

The aesthetic of Topeng Tua dance is not only reflected in the concept of the artworks worn by the dancers, including the tapel, costume, and the hair colour, but also depends closely to the movement technique of the dancer. In mastering the movement, there are some elements that needs to be cultivated by the dancers. Mastering the movement technique or wiraga needs to be optimally developed to establish aesthetics. In Bali dance, there are two aesthetic concepts that influence one another, that are taksu and pangus. Taksu can clearly be seen by the audiences by seeing the dancer's intensity, while pangus can be seen from its unified performance. Those two aesthetic concepts seem to be universal.

\section{REFERENCES}

Ahimsa-Putra, H. S. (2007). Etnosains untuk Etnokoreologi Nusantara. Etnokoreologi Nusantara: Batasan Kajian, Sistematika dan Aplikasi Keilmuannya. Surakarta: ISI Press.

Aryasa, I Wayan Madra. (1993). Materi Pokok Seni Sakral; 1-6; PAHD2433 / 2SKS. Jakarta: Direktorat Jenderal Bimbingan Masyarakat Hindu dan Budha dan Universitas Terbuka.

Bandem, I. M. (1980). Evolusi Tari Bali. Denpasar: Proyek Penggalian/Pembinaan Seni Budaya Klasik (tradisional) dan Baru.

Bandem, I. M., \& I Wayan D. (1982/1983). 
Pengembangan Tari Bali. Denpasar: Proyek Pengembangan Institut Kesenian Indonesia Sub/Bagian Proyek Pengembangan ASTI Denpasar.

Catra, I. N. (1997). Topeng Pajegan Sebagai Ritus Kehidupan. Mudra Jurnal Seni Budaya, 5(5), 251-265.

Dibia, I Wayan. (2012). Geliat Seni Pertunjukan Bali. Denpasar: Buku Arti.

Dibia, I Wayan. (2008). "Tari Bali dalam Kajian Etnokoreologi" dalam R.M. Pramutomo (ed.). Etnokoreologi Nusantara: Batasan Kajian, Sistematika dan
Aplikasi Keilmuannya. Surakarta: ISI Press.

Mantra, I. B. (1996). Landasan Kebudayaan Bali. Denpasar: Yayasan Dharma Sastra.

Mariasa, I Nengah. (2000). I Made Djimat (1948 -) Seorang Maestro Tari Topeng Bali di Era Globalisasi. Thesis. Yoyakarta: Universitas Gadjah Mada.

Warna, I W. (1978). Kamus Bali-Indonesia. Denpasar: Dinas Pengajaran Propinsi Daerah Tingkat I Bali. 